\title{
High-frequency Audiometry Hearing on Monitoring of Individuals Exposed to Occupational Noise: A Systematic Review
}

\author{
Cleonice Aparecida Silva Antonioli ${ }^{1}$ Teresa Maria Momensohn-Santos ${ }^{1,2}$ Tatiana Aparecida Silva Benaglia ${ }^{3}$ \\ ${ }^{1}$ Specialization on Advanced Audition, Instituto de Estudos Avançados \\ da Audição, São Paulo, SP, Brazil \\ 2 Audiologist, PUC, São Paulo, São Paulo, Brazil \\ 3 Statistics, UNICAMP, Campinas, São Paulo, Brazil \\ Address for correspondence Cleonice Aparecida Silva Antonioli, Fga, \\ Instituto de Estudos Avançados da Audição, Rua Dr. Albuquerque Lins, \\ 537 - Santa Cecilia, SP Campinas, São Paulo 13034-673, SP, Brazil \\ (e-mail: cleoapsa@yahoo.com.br).
}

Int Arch Otorhinolaryngol 2016;20:281-289.

\begin{abstract}
Introduction The literature reports on high-frequency audiometry as one of the exams used on hearing monitoring of individuals exposed to high sound pressure in their work environment, due to the method́s greater sensitivity in early identification of hearing loss caused by noise. The frequencies that compose the exam are generally between 9 $\mathrm{KHz}$ and $20 \mathrm{KHz}$, depending on the equipment.

Objective This study aims to perform a retrospective and secondary systematic revision of publications on high-frequency audiometry on hearing monitoring of individuals exposed to occupational noise.

Data Synthesis This systematic revision followed the methodology proposed in the Cochrane Handbook, focusing on the question: "Is High-frequency Audiometry more sensitive than Conventional Audiometry in the screening of early hearing loss individuals exposed to occupational noise?" The search was based on PubMed data, Base, Web of Science (Capes), Biblioteca Virtual em Saúde (BVS), and in the references cited in identified and selected articles. The search resulted in 6059 articles in total. Of these,

Keywords

- high-frequency

- hearing loss caused by noise

- hearing loss

- hearing tests

- hearing

- monitoring only six studies were compatible with the criteria proposed in this study.

Conclusion The performed meta-analysis does not definitively answer the study's proposed question. It indicates that the $16 \mathrm{KHz}$ high frequency audiometry (HFA) frequency is sensitive in early identification of hearing loss in the control group (medium difference ( $M D=8.33)$ ), as well as the $4 \mathrm{KHz}$ frequency $(C A)$, this one being a little less expressive $(M D=5.72)$. Thus, others studies are necessary to confirm the HFA importance for the early screening of hearing loss on individuals exposed to noise at the workplace.
\end{abstract}

\section{Introduction}

The hearing limit can be influenced by several factors intrinsic or extrinsic to the individual. A few are: age, heredity, head trauma, smoking, systemic diseases, exposure to chemical substances, and/or occupational and extra occupational noise.

received

August 27, 2015

accepted

October 11, 2015

published online

December 14, 2015
Nowadays, noise is one of the most frequent problems in many different societies, whether at work or outside of it. When not managed effectively, it can lead to irreversible alterations in the ear structure, resulting in hearing loss. ${ }^{1}$

In the labor process, noise is common, ${ }^{2-4}$ and considered to be the second most common cause of hearing loss in adults, after prebycusis. ${ }^{5}$
Copyright $\odot 2016$ by Thieme Publicações License terms Ltda, Rio de Janeiro, Brazil
DOI http://dx.doi.org/

10.1055/s-0035-1570072. ISSN 1809-9777.

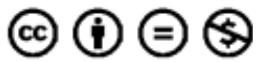


Despite the legal requirements, actions by several health professionals, safety at work initiatives, and union interventions, the productivity dynamics still generate a noisy work environment putting workers' hearing at risk. ${ }^{6}$

There are endless actions implemented to try to control the occupational noise; however, they are not always effective. The use of auditory Personal Protection Equipment (PPE), tone audiometry, as well as historical knowledge of hearing loss are not always sufficient to keep workerś hearing limits stable, as recommended by Brazilian decree 19/1998 from the Ministry of Labor. ${ }^{7}$ Nonetheless, certain variables may intervene and contribute to the triggering of hearing loss and/or its progression, even in the work environment. These include the type and usage of the personal hearing protection equipment (PPEs), ${ }^{8}$ the efficiency of the equipment over a long period of usage time, individual sensitivity, maintenance on the noise source equipment, and the different raw materials used in production environment (density, resistance).

The auditive monitoring and management of the individual exposed to occupational noise can show deficits when the available resources are limited to only conventional audiometry data (auditory threshold of the worker exposed to noise), to dosimetry (level of exposure to noise) and to the use of PPEs. Conventional audiometry is a procedure guaranteed by law for tracking the hearing capacity of workers exposed to noise, but does not prematurely identify any hearing alterations. It is an important, thought limited, resource for inhibitory actions in the progression of hearing loss in monitored individual, whose auditory deficit reflect in health, social security, and indemnifying statistics in the company.

Studies suggest that high-frequency audiometry (from $9 \mathrm{kHz}$ to $20 \mathrm{kHz}$ ) is an additional and important test to identify an initial hearing loss, as it is more sensitive to noise than conventional audiometry, ${ }^{9,10}$ even though there is no consensus on the standardization of the procedure (calibration, methodology, results, and analysis). ${ }^{11,12}$ This study aims to answer whether high-frequency audiometry is more sensitive than conventional audiometry in the tracking of premature hearing loss in individuals exposed to occupational noise. Our objective is to perform a secondary retrospective systematic review with a meta-analysis on high-frequency audiometry used in monitoring high-noise pressure on exposed workers' hearing health.

\section{Review of Literature}

The guidelines to this systematic review were suggested by Cochrane Handbook and include: formulation of a research question, localization, selection, and gathering of scientific articles as well as their critical evaluation. ${ }^{13}$ Our investigation question was: "Is the high-frequency audiometry more sensitive than the conventional audiometry in tracking the premature hearing loss in occupational noise exposed individuals?" Literature research was conducted from March 10 to September 30, 2014, based on the following online data: PubMed, Embase, Web of Science (Capes), and Biblioteca Virtual em Saúde. The keywords were selected from the Health Science Keywords list (DeCS). ${ }^{14}$ They are: Audiometry; Hearing Loss, High-Frequency; Hearing Loss, Noise-Induced;
Hearing Loss; Hearing Tests; Hearing; Monitoring; Noise, Occupational; Occupational Health. For the article research, the keywords were combined in the following way: Audiometry and monitoring and occupational hearing loss, highfrequency and audiometry and occupational health; Hearing Loss, High-Frequency; Hearing Loss, Noise-Induced and monitoring and audiometry; Hearing Loss, Noise-Induced and monitoring; Hearing tests and monitoring and occupational health. We also manually researched the bibliography from the selected articles. To evaluate the quality of the selected articles, we adopted a recommendation from the Committee to Advise on Tropical Medicine and Travel (CATMAT) regarding the recommendation grade $(A, B, C, D$, and $E$, with $A$ being the most recommended for usage and $\mathrm{E}$, the least) and the evidence level category (classification from I to VII, in which level I is the highest and VII the lowest). ${ }^{15-17}$

Two authors participated independently in the elaboration of the search strategies based on data, the study selection based on the including and excluding criteria, the critical evaluation of the studies for inclusion in the systematic review, and in the interpretation of the results.

The inclusion criteria for this systematic review were: (1) studies with an approach to the objective explicit in the title, abstract, or article body; (2) publication date within the past 11 years; (3) research that includes a study group and a control group; (4) results from similar statistics tests; (5) at least one frequency matching the other studies; and (6) studies in English, Portuguese, and Spanish.

We excluded all repeated articles.

\section{Discussion}

The search for the keywords above in the database used resulted in a sum of 6059 articles. Remaining after the filters of the publication year (3582 articles) and of the filter: languages (3569 articles).

After titles and abstracts screening and the manual search in bibliographic references, 3854 articles were identified. Observing the inclusion and exclusion criteria adopted, 68 were selected. From these, we excluded 31 because they were in more than one database. Thus, 37 articles remained for full text analysis. From the selection of abstracts found, which were relevant for the proposed question, we retrieved the articles in full text. After the reading of only six studies ${ }^{5,10,18-21}$ matched the proposed inclusion criteria (-Fig. 1).

Next, we gathered data from the selected articles for the following variables: reference data of article; identification of the study type; investigation of the analyzed population and control group (CG); evaluated frequencies in high-frequency audiometry (HFA) and conventional audiometry (CA); inclusion and exclusion criteria; ethics committee and consent term use; analysis of the statistics used and outcomes (- Fig. 1).

We present the gathered data in these forms summarized in - Table 1.

The selected variables from the articles were author name, publication year, recommendation grade and evidence level, methodology, evaluated frequencies, objective, investigation group formation, sample size, and study outcome. 


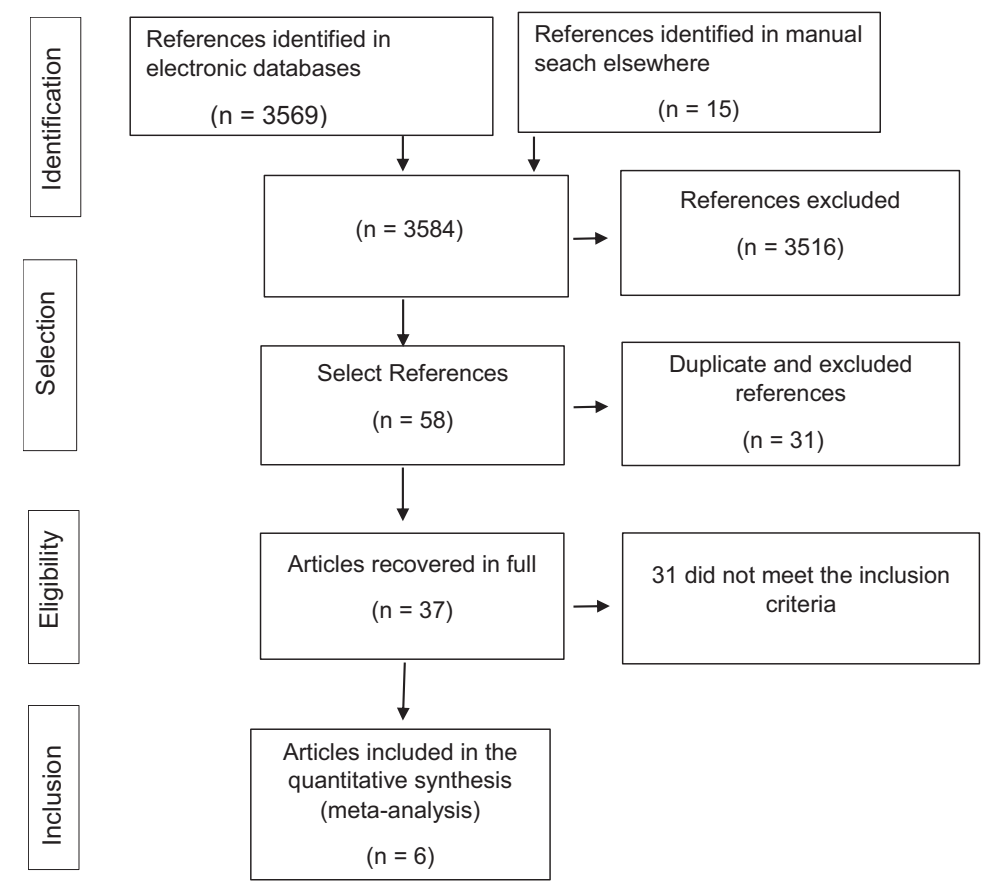

Fig. 1 Flow selection of items for a systematic review with meta-analysis.

In this study, the selected articles did not undergo a randomization process. They correspond to evidence level IV and a B 05 recommendation grade, which indicates moderate evidence for a cohort study.

Even though the selected articles refer to a specific sample group (workers exposed to occupational noise) with a common predetermined risk factor - in this case, noise - only two explicitly approached the research type and study outline in their methodology: the cohort study and the prospective cross-sectional study. The more explicit and clear the study type data, the methodological procedures used for the data gathering and its use in the analysis process, the better the chances of a reader understanding the outlines and limits of the study, as well as its findings.

The percentage related to the publication year of the selected articles was 17\% for 2004 and 2011, and 33\% for 2008 and 2014.

The sample size varied between 30 and 186 participants in the study group and 30 to 148 participants in the control group. Regarding the study subjects, $50 \%$ included both genders and $50 \%$ only males. There is no evidence that gender has any influence on the auditory limit or makes a difference when considering exposure to a high level of sound pressure. ${ }^{10}$ Age varied between 18 and 60 years old. Some studies (33\%) subdivided the age groups in decades to comprehend the influence of age on the auditory limit. It was possible to observe that individuals above 40 years old are more susceptible to presbycusis; however, the study by Mehrparvar ${ }^{10}$ did not see a significant difference in the variable age $(p=0.3)$ for both groups: exposed and control.

The frequencies referred to as the most sensitive in HFA among the studied population in the selected articles were: $14 \mathrm{kHz}$ for studies $1,2,3,4$, and 5 , and $16 \mathrm{kHz}$ for 1,2 , and 3 . Study number 6 analyzed only the frequency of $12 \mathrm{kHz}$, which was significant; however, it was not part of the meta-analysis as it was not contained in the methodology of the other studies. Study number 2 connects high frequency sensibility to an age below 40 years old. Above that age, there was a decrease in the sensibility, justified by the probable interference of presbycusis.

The studies $(1,4,5$, and 6$)$ that evaluated the difference of auditory limits in HFA between the left and right ears did not produce significant data. Similarly, studies that evaluated the difference between genders also did not reach significant data outcome.

The average auditory limits were higher for all frequencies in the study group (SG) when compared with control group (CG) in articles 1, 2, 4, and 5, being higher for the higher frequencies. The same occurred with the standard deviation, which, in general, was higher for SG than for CG, where higher values correlated with higher frequencies. In article number 6 , the averages and the standard deviations found for frequencies up to $3 \mathrm{kHz}$ varied for both groups, being larger in the control group in the left ear. In frequencies above $4 \mathrm{kHz}$, the highest averages and standard deviations concentrated in the SG. In study number 3, the averages of the auditory limits and the standard deviations were bigger for all subjects in the conventional audiometry group (CA).

The frequencies analyzed in the conventional audiometry were more constant then the high-frequency audiometry for the six selected studies ( $\mathbf{- T a b l e s} \mathbf{2}$ and $\mathbf{3}$ ). This can be justified with the existence of standardization only for the CA as well as the diversity/limitation of the equipment for the higher frequencies. Therefore, for the meta-analysis, we selected only the frequencies of $2 \mathrm{kHz}, 3 \mathrm{kHz}, 4 \mathrm{kHz}, 6 \mathrm{kHz}, 8 \mathrm{kHz}$, $10 \mathrm{kHz}, 14 \mathrm{kHz}$, and $16 \mathrm{kHz}$.

We grouped the ages in the second text to maintain the same pattern of the other studies. Creating an average, a standard deviation and a unique $p$ value for each analyzed 


\begin{tabular}{|c|c|c|c|}
\hline 总 & 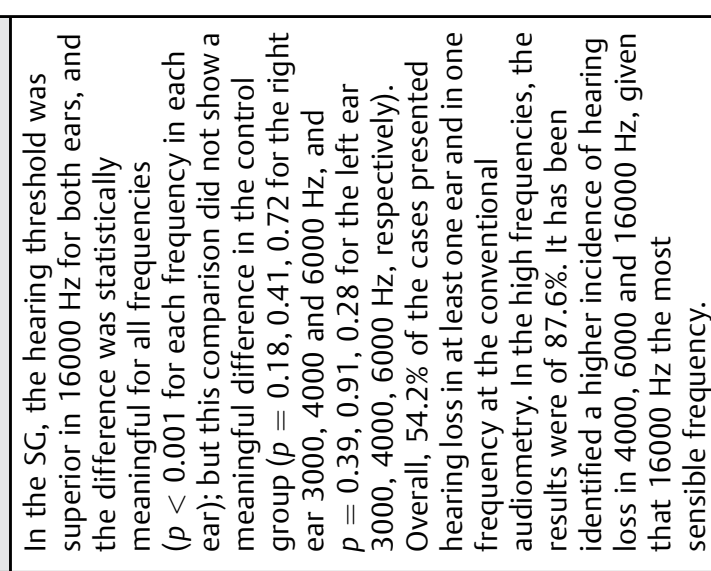 & 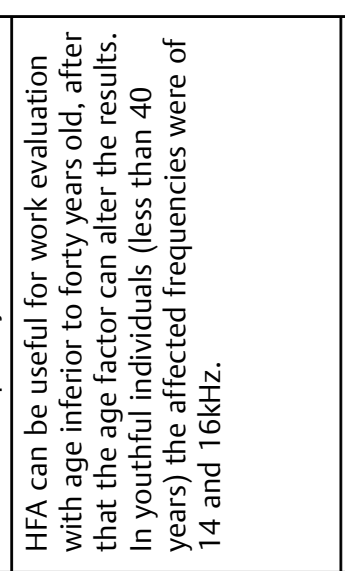 & 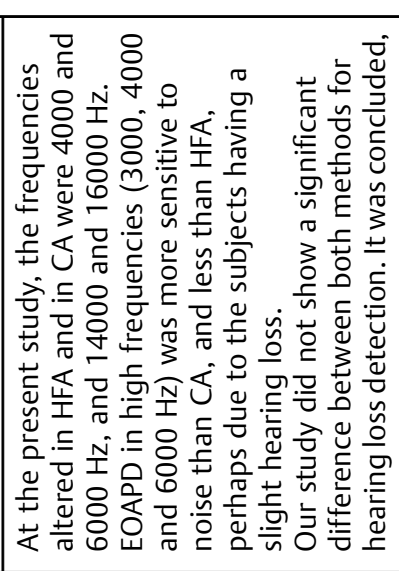 \\
\hline 言 & 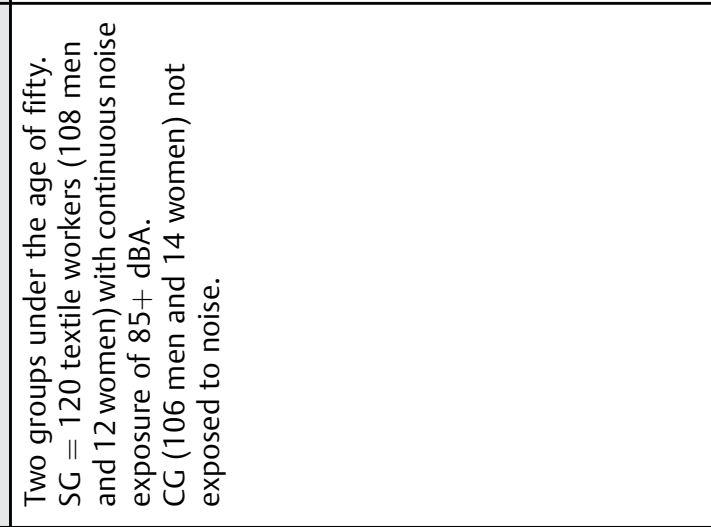 & 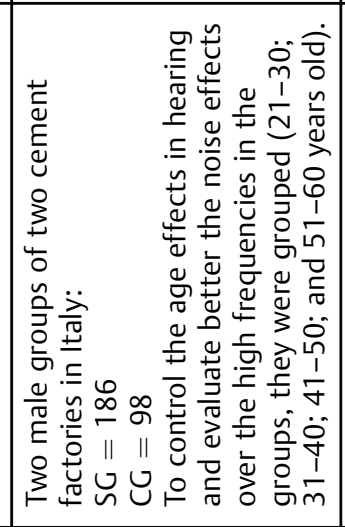 & 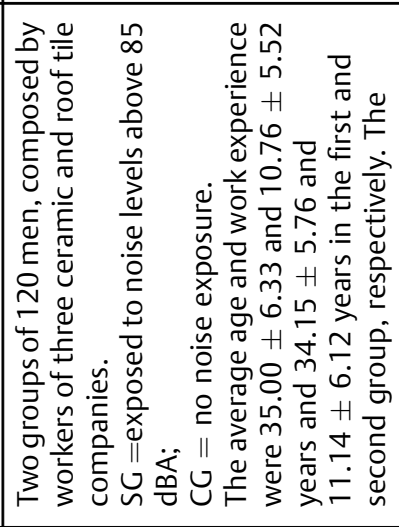 \\
\hline 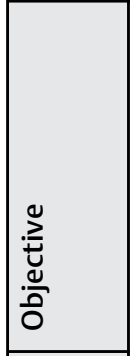 & 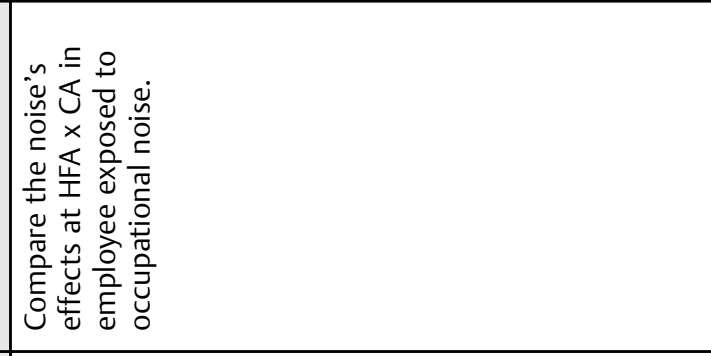 & 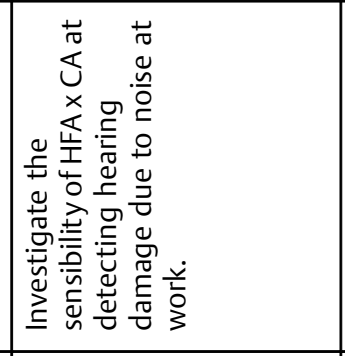 & 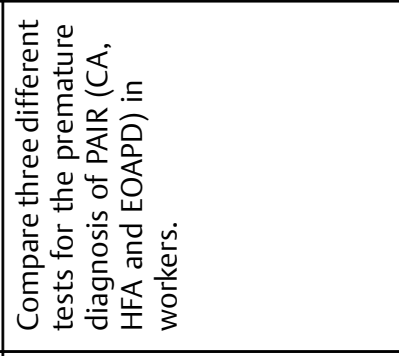 \\
\hline 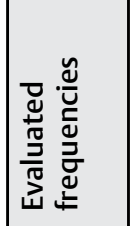 & 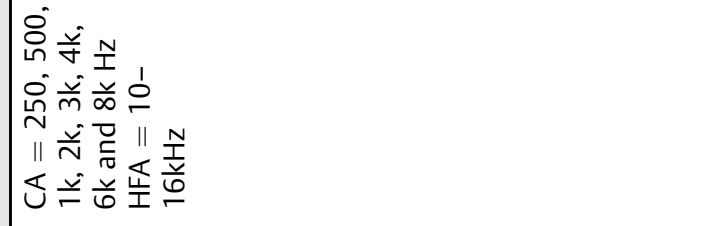 & 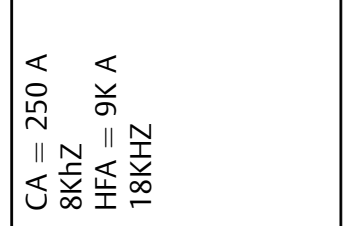 & 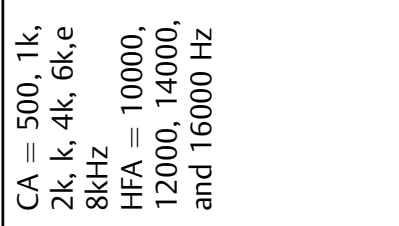 \\
\hline 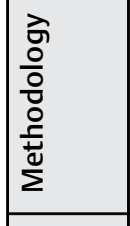 & 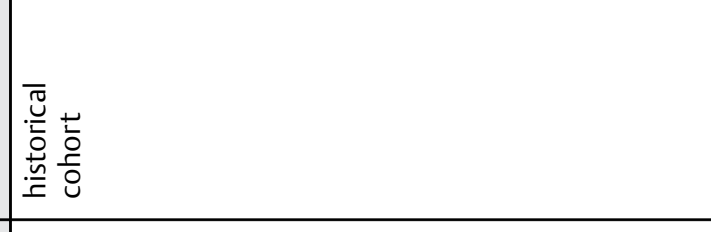 & 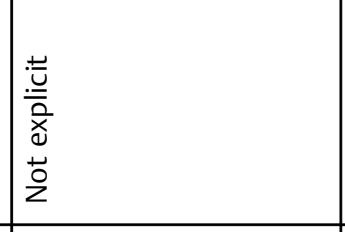 & 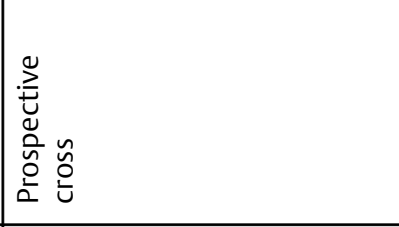 \\
\hline 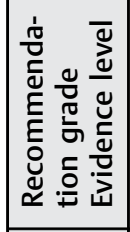 & \begin{tabular}{|ll} 
\\
\\
0
\end{tabular} & 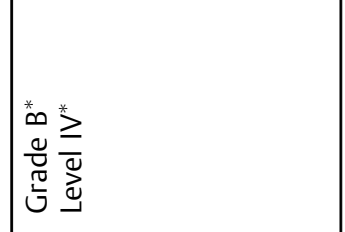 & 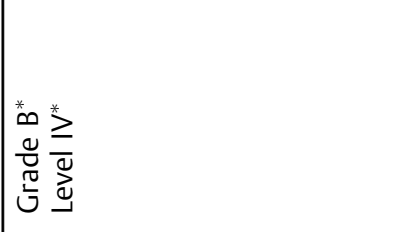 \\
\hline 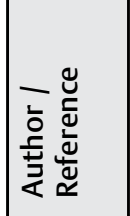 & 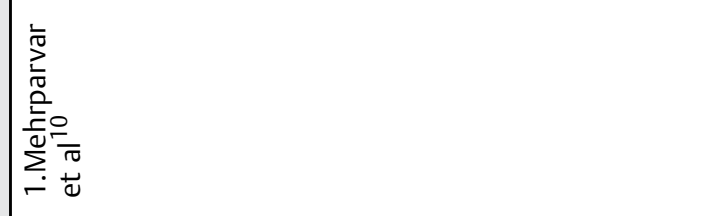 & 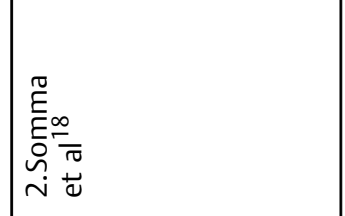 & 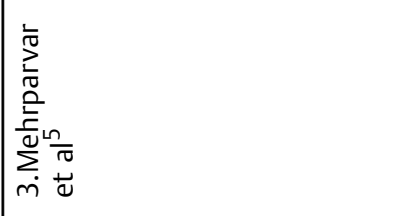 \\
\hline
\end{tabular}




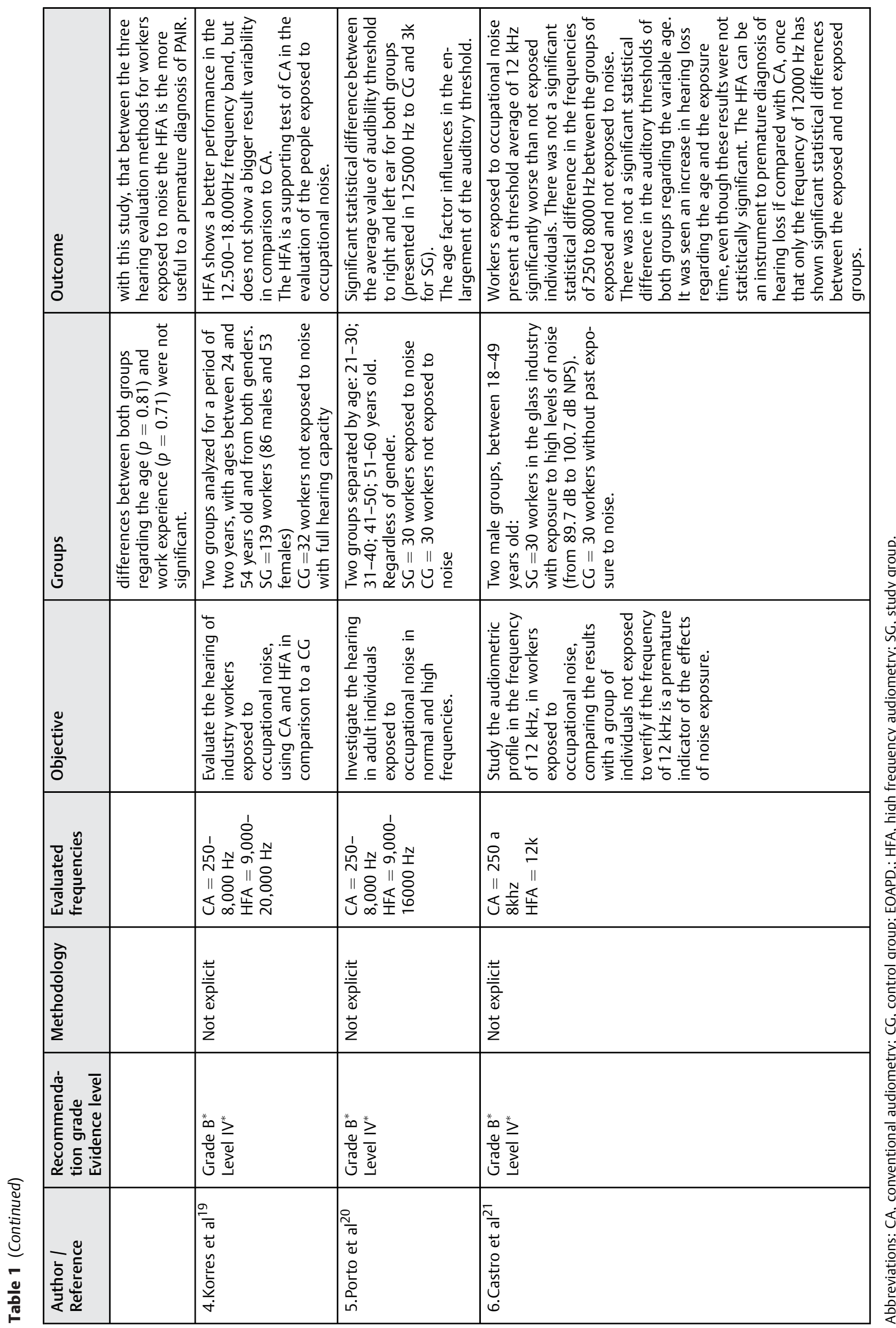


Table 2 General panorama of the analyzed frequencies

\begin{tabular}{|c|l|l|l|}
\hline $\mathbf{N}$ & Author $/$ Reference & $\begin{array}{l}\text { Frequencies evaluated } \\
\text { Common studies }\end{array}$ & Audiometry AAF \\
\hline 1 & Mehrparvar et $\mathrm{al}^{10}$ & $\begin{array}{l}\mathrm{CA}=250 \mathrm{~Hz}-8 \mathrm{KHz} \\
\mathrm{HFA}=10 \mathrm{KHz}-20 \mathrm{KHz}\end{array}$ & Interacoustic,Denmark-headphones kross R/80 \\
\hline 2 & Somma et $\mathrm{al}^{18}$ & $\begin{array}{l}\mathrm{CA}=250 \mathrm{~Hz}-8 \mathrm{KHz} \\
\mathrm{HFA}=9 \mathrm{~K}-18 \mathrm{KHz}\end{array}$ & Amplaid A3 19 - headphonesHDA200 (Wedemark, Germany) \\
\hline 3 & ${\text { Mehrparvar et } \mathrm{al}^{5}}^{5}$ & $\begin{array}{l}\mathrm{CA}=500 \mathrm{~Hz}-8 \mathrm{KHz} \\
\mathrm{HFA}=10 \mathrm{KHz}-16 \mathrm{KHz}\end{array}$ & Audiometry AC 40 - headphones R80 \\
\hline 4 & Korres et al ${ }^{19}$ & $\begin{array}{l}\mathrm{CA}=250 \mathrm{~Hz}-8 \mathrm{KHz} \\
\mathrm{HFA}=9 \mathrm{KHz}-20 \mathrm{KHz}\end{array}$ & Amplaid A321 - headphones HDA200 (Wedemark, Germany) \\
\hline 5 & Porto et $\mathrm{al}^{20}$ & $\begin{array}{l}\mathrm{CA}=250 \mathrm{~Hz}-8 \mathrm{KHz} \\
\mathrm{HFA}=9 \mathrm{KHz}-16 \mathrm{KHz}\end{array}$ & Audiometry SD50 Siemens -headphonesHD 200 (Wedemark, Germany) \\
\hline 6 & Castro et al ${ }^{21}$ & $\begin{array}{l}\mathrm{CA}=250 \mathrm{~Hz}-8 \mathrm{KHz} \\
\mathrm{HFA}=12 \mathrm{kHz}\end{array}$ & Audiometry CSI 61 -headphonesTDH-39p. \\
\hline
\end{tabular}

Abbreviations: CA, conventional audiometry; HFA, high-frequency audiometry.

Table 3 General panorama of the common analyzed frequencies in the studies

\begin{tabular}{|c|c|c|c|}
\hline $\mathbf{N}$ & Author / Reference & $\begin{array}{l}\text { Frequencies Evaluated } \\
\text { Common Studies }\end{array}$ & Audiometry AAF \\
\hline 1 & Mehrparvar et al ${ }^{10}$ & $\begin{array}{l}\mathrm{CA}=2 \mathrm{KHz} ; 3 \mathrm{KHz} ; 4 \mathrm{KHz} ; 6 \mathrm{KHz} ; 8 \mathrm{KHz} \\
\mathrm{HFA}=10 \mathrm{KHz} ; 14 \mathrm{KHz} \text { e } 16 \mathrm{KHz}\end{array}$ & Interacoustic,Denmark-headphones kross R/80 \\
\hline 2 & Somma et $\mathrm{al}^{18}$ & $\begin{array}{l}\mathrm{CA}=2 \mathrm{KHz} ; 3 \mathrm{KHz} ; 4 \mathrm{KHz} ; 6 \mathrm{KHz} ; 8 \mathrm{KHz} \\
\mathrm{HFA}=10 \mathrm{KHz} ; 14 \mathrm{KHz} \text { e } 16 \mathrm{KHz}\end{array}$ & $\begin{array}{l}\text { Amplaid A3 } 19 \text { - headphonesHDA200 } \\
\text { (Wedemark, Germany) }\end{array}$ \\
\hline 3 & Mehrparvar et al ${ }^{5}$ & $\begin{array}{l}\mathrm{CA}=2 \mathrm{KHz} ; 3 \mathrm{KHz} ; 4 \mathrm{KHz} ; 6 \mathrm{KHz} ; 8 \mathrm{KHz} \\
\mathrm{HFA}=10 \mathrm{KHz} ; 14 \mathrm{KHz} \text { e } 16 \mathrm{KHz}\end{array}$ & Audiometry AC 40 - headphones R80 \\
\hline 4 & Korres et al ${ }^{19}$ & $\begin{array}{l}\mathrm{CA}=2 \mathrm{KHz} ; 4 \mathrm{KHz} ; 8 \mathrm{KHz} \\
\mathrm{HFA}=10 \mathrm{KHz} ; 14 \mathrm{KHz} \text { e } 16 \mathrm{KHz}\end{array}$ & $\begin{array}{l}\text { Amplaid A321 - headphones HDA200 } \\
\text { (Wedemark, Germany) }\end{array}$ \\
\hline 5 & Porto et $\mathrm{al}^{20}$ & $\begin{array}{l}\mathrm{CA}=2 \mathrm{KHz} ; 3 \mathrm{KHz} ; 4 \mathrm{KHz} ; 6 \mathrm{KHz} ; 8 \mathrm{KHz} \\
\mathrm{HFA}=10 \mathrm{KHz} ; 14 \mathrm{KHz} \text { e } 16 \mathrm{KHz}\end{array}$ & $\begin{array}{l}\text { Audiometry SD50 Siemens -headphonesHD } 200 \\
\text { (Wedemark, Germany) }\end{array}$ \\
\hline 6 & Castro et $\mathrm{al}^{21}$ & $\mathrm{CA}=2 \mathrm{KHz} ; 3 \mathrm{KHz} ; 4 \mathrm{KHz} ; 6 \mathrm{KHz} ; 8 \mathrm{KHz}$ & Audiometry GSI 61 -headphonesTDH-39p. \\
\hline
\end{tabular}

Abbreviations: CA, conventional audiometry; HFA, high-frequency audiometry.

frequency. The other studies $(1,3,4,5$, and 6$)$ had, individually, the results obtained by ear grouped by frequency. This way, each frequency got an average reference value for both ears. The alteration made the meta-analysis possible.
For the meta-analysis, we used the $\mathrm{R}$ software ( $\mathrm{R}$ Core Team, 2012), a statistics program that allows the calculation of the study data that are not from an interference, as the cross-sectional and cohort. This provides a summarized

\begin{tabular}{|c|c|c|c|c|c|c|c|c|c|c|}
\hline \multirow[t]{2}{*}{ Study } & \multicolumn{3}{|c|}{ Exposed } & \multicolumn{3}{|c|}{ Control } & \multirow{2}{*}{$\begin{array}{l}\text { Mean } \\
\text { difference }\end{array}$} & \multirow[t]{2}{*}{ MD } & \multirow[t]{2}{*}{$95 \% \mathrm{Cl}$} & \multirow[t]{2}{*}{ W (fixed) } \\
\hline & Total & Mean & SD & Total & Mean & SD & & & & \\
\hline Mehrparvar et al ${ }^{10}$ & 120 & 12.9 & 8.5 & 120 & 7.1 & 3.2 & & 5.8 & {$[4.17 ; 7.43]$} & $11.4 \%$ \\
\hline Somma et $\mathrm{al}^{18}$ & 186 & 12.0 & 6.9 & 98 & 10.3 & 1.2 & & 1.70 & {$[0.68 ; 2.72]$} & $28.8 \%$ \\
\hline Mehrparvar et al ${ }^{5}$ & 142 & 7.9 & 3.4 & 121 & 11.0 & 4.3 & & -3.70 & {$[-4.05 ;-2.15]$} & $33.3 \%$ \\
\hline Korres et al ${ }^{19}$ & 139 & 12.7 & 11.2 & 32 & 7.0 & 5.0 & & 5.70 & {$[3.16 ; 8.24]$} & $4.6 \%$ \\
\hline Porto et $\mathrm{al}^{20}$ & 60 & 10.8 & 15.9 & 60 & 4.7 & 7.1 & & 6.10 & {$[1.69 ; 10.51]$} & $1.5 \%$ \\
\hline Castro et $\mathrm{al}^{21}$ & 30 & 5.4 & 2.3 & 30 & 5.8 & 2.5 & & -0.40 & {$[-1.62 ; 0.82]$} & $20.3 \%$ \\
\hline Fixed effect model & 677 & & & 461 & & & & 0.39 & {$[-0.15 ; 0.94]$} & $100 \%$ \\
\hline
\end{tabular}

Fig. 2 Analysis for the frequency $2 \mathrm{KHz}$. 
High-frequency Audiometry Hearing on Individuals Exposed to Occupational Noise Antonioli et al. 287

\begin{tabular}{|c|c|c|c|c|c|c|c|c|c|c|}
\hline \multirow[t]{2}{*}{ Study } & \multicolumn{3}{|c|}{ Exposed } & \multicolumn{3}{|c|}{ Control } & \multirow{2}{*}{$\begin{array}{l}\text { Mean } \\
\text { difference }\end{array}$} & \multirow[t]{2}{*}{ MD } & \multirow[t]{2}{*}{$95 \% \mathrm{Cl}$} & \multirow[t]{2}{*}{ W (fixed) } \\
\hline & Total & Mean & SD & Total & Mean & SD & & & & \\
\hline Mehrparvar et al ${ }^{10}$ & 120 & 8.6 & 11.9 & 120 & 8.6 & 3.7 & & 0.00 & {$[-2.23 ; 2.23]$} & $13.1 \%$ \\
\hline Somma et $\mathrm{al}^{18}$ & 186 & 16.8 & 9.6 & 98 & 10.3 & 1.2 & & 6.50 & {$[5.10 ; 7.90]$} & $33.3 \%$ \\
\hline Mehrparvar et al ${ }^{5}$ & 142 & 7.9 & 3.8 & 121 & 13.2 & 7.5 & & -5.30 & {$[-6.78 ;-3.82]$} & $30.0 \%$ \\
\hline Porto et $\mathrm{al}^{20}$ & 60 & 12.2 & 16.8 & 60 & 3.8 & 9.1 & & 8.40 & {$[3.57 ; 13.23]$} & $2.8 \%$ \\
\hline Castro et $\mathrm{al}^{21}$ & 30 & 5.8 & 3.8 & 30 & 6.2 & 3.2 & & -0.40 & {$[-2.18 ; 1.38]$} & $20.7 \%$ \\
\hline Fixed effect model & 538 & & & 429 & & & & 0.73 & {$[-0.08 ; 1.54]$} & $100 \%$ \\
\hline Heterogeneity: I-sq & - -8 & O & 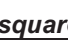 & -21 & $0<0$ & & $\begin{array}{lllll}-10 & -5 & 0 & 5 & 10\end{array}$ & & & \\
\hline
\end{tabular}

Fig. 3 Analysis for the frequency $3 \mathrm{KHz}$.

\begin{tabular}{|c|c|c|c|c|c|c|c|c|c|c|}
\hline \multirow[t]{2}{*}{ Study } & \multicolumn{3}{|c|}{ Exposed } & \multicolumn{3}{|c|}{ Control } & \multirow[t]{2}{*}{ Mean difference } & \multirow[t]{2}{*}{ MD } & \multirow[t]{2}{*}{$95 \% \mathrm{Cl}$} & \multirow[t]{2}{*}{ W (fixed) } \\
\hline & Total & Mean & SD & Total & Mean & SD & & & & \\
\hline Mehrparvar et $\mathrm{al}^{10}$ & 120 & 21.2 & 13.9 & 120 & 9.5 & 4.4 & & 11.70 & {$[9.09 ; 14.31]$} & $12.5 \%$ \\
\hline Somma et $\mathrm{al}^{18}$ & 186 & 22.1 & 10.2 & 98 & 11.1 & 1.4 & & 11.00 & {$[9.51 ; 12.49]$} & $38.1 \%$ \\
\hline Mehrparvar et al ${ }^{5}$ & 142 & 9.4 & 3.4 & 121 & 16.6 & 10.9 & & -7.20 & {$[-9.22 ;-5.18]$} & $20.7 \%$ \\
\hline Korres et $\mathrm{al}^{19}$ & 139 & 25.9 & 17.5 & 32 & 9.0 & 7.1 & & 16.90 & {$[13.09 ; 20.71]$} & $5.8 \%$ \\
\hline Porto et $\mathrm{al}^{20}$ & 60 & 18.2 & 18.5 & 60 & 4.3 & 8.2 & & 13.90 & {$[8.78 ; 19.02]$} & $3.2 \%$ \\
\hline Castro et $\mathrm{al}^{21}$ & 30 & 7.0 & 4.7 & 30 & 6.3 & 3.4 & & 0.70 & {$[-1.38 ; 2.78]$} & $19.7 \%$ \\
\hline Fixed effect model & 677 & & & 461 & & & & 5.72 & {$[4.80 ; 6.65]$} & $100 \%$ \\
\hline Heterogeneity: I-sq & $e d=9$ & $\% ; t$ & qua & $=83$. & $p<0$ & & $-20-1001020$ & & & \\
\hline
\end{tabular}

Fig. 4 Analysis for the frequency $4 \mathrm{KHz}$.

measure with the respective confidence grade, a $95 \%$ confidence grade $(\mathrm{CI})$ shown in the forest plot, with a heterogeneity evaluation across the studies.

In the analysis of the auditory limits for the frequencies in CA and HFA, we found a heterogeneity for all frequencies analyzed in this study (values above $90 \%$ in I-squared) which shows the difference in the statistical results, which were possibly the result of methodological heterogeneity.
-Figs. 2 and $\mathbf{3}$ show that the data obtained in the metaanalysis were not significant in the frequencies of $2 \mathrm{kHz}$ with confidence gaps: $-0.15 ; 0.94$ and with medium difference (MD) of 0.39 and $3 \mathrm{kHz}$ with confidence gaps: 0.08 ; 1.54 with MD of 0.73 , for both groups in this study.

-Figs. 4, 5, 6, 7, 8, and 9 indicate significant values for the other frequencies ( $4 \mathrm{kHz}, 6 \mathrm{kHz}, 8 \mathrm{kHz}, 10 \mathrm{kHz}, 14 \mathrm{kHz}$, and 16 $\mathrm{kHz}$ ). The highest result was the frequency of $16 \mathrm{kHz}$ in

\begin{tabular}{|c|c|c|c|c|c|c|c|c|c|c|}
\hline \multirow[t]{2}{*}{ Study } & \multicolumn{3}{|c|}{ Exposed } & \multicolumn{3}{|c|}{ Control } & \multirow[t]{2}{*}{ Mean difference } & \multirow[t]{2}{*}{ MD } & \multirow[t]{2}{*}{$95 \% \mathrm{Cl}$} & \multirow[t]{2}{*}{ W (fixed) } \\
\hline & Total & Mean & SD & Total & Mean & SD & & & & \\
\hline Mehrparvar et $\mathrm{al}^{10}$ & 120 & 22.5 & 14.8 & 120 & 11.0 & 5.2 & & 11.50 & {$[8.69 ; 14.31]$} & $14.5 \%$ \\
\hline Somma et al ${ }^{18}$ & 186 & 22.0 & 10.7 & 98 & 12.6 & 2.7 & & 9.40 & {$[7.77 ; 11.03]$} & $43.2 \%$ \\
\hline Mehrparvar et al ${ }^{5}$ & 142 & 11.1 & 5.2 & 121 & 20.2 & 13.5 & & -9.10 & {$[-11.65 ;-6.55]$} & $17.6 \%$ \\
\hline Porto et $\mathrm{al}^{20}$ & 60 & 24.8 & 19.0 & 60 & 12.5 & 11.4 & & 12.30 & {$[6.69 ; 17.91]$} & $3.6 \%$ \\
\hline Castro et $\mathrm{al}^{21}$ & 30 & 8.3 & 4.8 & 30 & 7.8 & 4.4 & & 0.50 & {$[-1.83 ; 2.83]$} & $21.1 \%$ \\
\hline Fixed effect model & 538 & & & 429 & & & & 4.69 & {$[3.62 ; 5.76]$} & $100 \%$ \\
\hline Heterogeneity: I-sc & $d=$ & 0. & 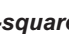 & & & 001 & 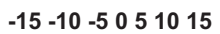 & & & \\
\hline
\end{tabular}

Fig. 5 Analysis for the frequency $6 \mathrm{KHz}$. 
High-frequency Audiometry Hearing on Individuals Exposed to Occupational Noise Antonioli et al.

\begin{tabular}{|c|c|c|c|c|c|c|c|c|c|c|}
\hline \multirow[t]{2}{*}{ Study } & \multicolumn{3}{|c|}{ Exposed } & \multicolumn{3}{|c|}{ Control } & \multirow[t]{2}{*}{ Mean difference } & \multirow[t]{2}{*}{ MD } & \multirow[t]{2}{*}{$95 \% \mathrm{Cl}$} & \multirow[t]{2}{*}{ W (fixed) } \\
\hline & Total & Mean & SD & Total & Mean & SD & & & & \\
\hline Mehrparvar et al ${ }^{10}$ & 120 & 19.4 & 15.6 & 120 & 10.3 & 4.8 & & 9.10 & {$[6.18 ; 12.02]$} & $14.7 \%$ \\
\hline Somma et $\mathrm{al}^{18}$ & 186 & 22.6 & 12.2 & 98 & 13.0 & 3.6. & & 9.60 & {$[7.71 ; 11.49]$} & $35.1 \%$ \\
\hline Mehrparvar et al ${ }^{5}$ & 142 & 10.9 & 4.9 & 121 & 18.0 & 13.6 & & -7.10 & {$[-9.65 ;-4.55]$} & $19.3 \%$ \\
\hline Korres et $\mathrm{al}^{19}$ & 139 & 25.9 & 18.9 & 32 & 13.0 & 8.9 & & 12.90 & {$[8.50 ; 17.30]$} & $6.5 \%$ \\
\hline Porto et $\mathrm{al}^{20}$ & 60 & 18.2 & 21.0 & 60 & 6.7 & 13.0 & & 11.50 & {$[5.25 ; 17.75]$} & $3.2 \%$ \\
\hline Castro et $\mathrm{al}^{21}$ & 30 & 9.8 & 5.2 & 30 & 8.3 & 4.4 & & 1.50 & {$[-0.94 ; 3.94]$} & $21.2 \%$ \\
\hline Fixed effect model & 677 & & & 461 & & & & 4.87 & {$[3.75 ; 5.99]$} & $100 \%$ \\
\hline Heterogeneity: I-so & $1-0$ & $0<$ & quar & -57 & 10 & & $\begin{array}{l}-15-10-50510 \\
15\end{array}$ & & & \\
\hline
\end{tabular}

Fig. 6 Analysis for the frequency $8 \mathrm{KHz}$.

\begin{tabular}{|c|c|c|c|c|c|c|c|c|c|c|}
\hline \multirow[t]{2}{*}{ Study } & \multicolumn{3}{|c|}{ Exposed } & \multicolumn{3}{|c|}{ Control } & \multirow[t]{2}{*}{ Mean difference } & \multirow[t]{2}{*}{ MD } & \multirow[t]{2}{*}{$95 \% \mathrm{Cl}$} & \multirow[t]{2}{*}{ W (fixed) } \\
\hline & Total & Mean & SD & Total & Mean & SD & & & & \\
\hline Mehrparvar et a $\left.\right|^{10}$ & 120 & 9.8 & 12.9 & 120 & 5.1 & 4.3 & & 4.70 & {$[2.27 ; 7.13]$} & $20.8 \%$ \\
\hline Somma et al ${ }^{18}$ & 186 & 27.2 & 13.3 & 98 & 14.7 & 4.7 & & 12.50 & {$[10.37 ; 14.63]$} & $27.3 \%$ \\
\hline Mehrparvar et $\mathrm{al}^{5}$ & 142 & 5.3 & 4.5 & 121 & 9.8 & 8.0 & & -4.50 & {$[-6.11 ;-2.89]$} & $47.8 \%$ \\
\hline Korres et al ${ }^{19}$ & 139 & 27.9 & 24.6 & 32 & 15.1 & 18.5 & & 12.80 & {$[5.20 ; 20.40]$} & $2.1 \%$ \\
\hline Porto et al ${ }^{20}$ & 60 & 23.1 & 24.6 & 60 & 10.8 & 19.3 & & 12.30 & {$[4.39 ; 20.21]$} & $2.0 \%$ \\
\hline Fixed effect model & 647 & & & 431 & & & & 2.75 & {$[1.64 ; 3.86]$} & $100 \%$ \\
\hline
\end{tabular}

Fig. 7 Analysis for the frequency $10 \mathrm{KHz}$.

\begin{tabular}{|c|c|c|c|c|c|c|c|c|c|c|}
\hline \multirow[t]{2}{*}{ Study } & \multicolumn{3}{|c|}{ Exposed } & \multicolumn{3}{|c|}{ Control } & \multirow{2}{*}{$\begin{array}{l}\text { Mean } \\
\text { difference }\end{array}$} & \multirow[t]{2}{*}{ MD } & \multirow[t]{2}{*}{$95 \% \mathrm{Cl}$} & \multirow[t]{2}{*}{ W (fixed) } \\
\hline & Total & Mean & SD & Total & Mean & SD & & & & \\
\hline Mehrparvar et a $1^{10}$ & 120 & 17.4 & 18.5 & 120 & 6.8 & 8.2 & & 10.60 & {$[6.98 ; 14.22]$} & $19.2 \%$ \\
\hline Somma et $\mathrm{al}^{18}$ & 186 & 41.5 & 12.2 & 98 & 24.7 & 10.0 & & 16.80 & {$[14.16 ; 19.44]$} & $36.0 \%$ \\
\hline Mehrparvar et $\mathrm{al}^{5}$ & 142 & 7.1 & 8.2 & 121 & 20.4 & 12.0 & & -13.30 & {$[-15.83 ;-10.77]$} & $39.4 \%$ \\
\hline Korres et al ${ }^{19}$ & 139 & 48.2 & 37.4 & 32 & 21.4 & 26.8 & & 26.80 & {$[15.63 ; 37.97]$} & $2.0 \%$ \\
\hline Porto et $\mathrm{al}^{20}$ & 60 & 31.1 & 26.1 & 60 & 13.4 & 22.9 & & 17.70 & {$[8.91 ; 26.49]$} & $3.3 \%$ \\
\hline Fixed effect model & 647 & & & 431 & & & & 3.97 & {$[2.38 ; 5.55]$} & $100 \%$ \\
\hline
\end{tabular}

Fig. 8 Analysis for the frequency $14 \mathrm{KHz}$.

the control group with a confidence gap of 6.959 .72 and MD of 8.33 .

The study done by Somma et al. shows a measurement of the effect (odds ratio) that is larger for most the analyzed frequencies ( $3 \mathrm{kHz}, 4 \mathrm{kHz}, 6 \mathrm{kHz}, 8 \mathrm{kHz}$, and $16 \mathrm{kHz}$ ) which contributed to a result favorable to the control group. Even though the study from Mehrparvar et al. indicates a greater effect for the study group in the frequencies of $10 \mathrm{kHz}$ and $14 \mathrm{kHz}$, it was not determinant in the final result, which kept favorable to the control group. The most expressive results were for the frequencies of $16 \mathrm{kHz}$ $(\mathrm{MD}=8.33) ; 4 \mathrm{kHz}(\mathrm{MD}=5.75)$; followed by $8 \mathrm{kHz}$ ( $\mathrm{MD}$ $=4.87), 6 \mathrm{kHz}(\mathrm{MD}=4.69)$, and $14 \mathrm{kHz}(\mathrm{MD}=3.97)$.

The confidence gaps $(\mathrm{CI})$ were larger for all frequencies analyzed in the study by Porto et al. in the frequencies of $2 \mathrm{kHz}, 3 \mathrm{kHz}, 4 \mathrm{kHz}, 6 \mathrm{kHz}, 8 \mathrm{kHz}$, and $10 \mathrm{kHz}$, with a variation in the $\mathrm{CI}$ from 9 to 16 . The study by Korres et al. ${ }^{19}$ presented the largest confidence gaps in the frequencies of $14 \mathrm{kHz}$ and $16 \mathrm{kHz}$, with a variation between 23 and 20 . 


\begin{tabular}{|c|c|c|c|c|c|c|c|c|c|c|}
\hline \multirow[t]{2}{*}{ Study } & \multicolumn{3}{|c|}{ Exposed } & \multicolumn{3}{|c|}{ Control } & \multirow{2}{*}{$\begin{array}{l}\text { Mean } \\
\text { difference }\end{array}$} & \multirow[t]{2}{*}{ MD } & \multirow[t]{2}{*}{$95 \% \mathrm{Cl}$} & \multirow[t]{2}{*}{ W (fixed) } \\
\hline & Total & Mean & SD & Total & Mean & SD & & & & \\
\hline Mehrparvar et $\mathrm{al}^{10}$ & 120 & 39.4 & 17.0 & 120 & 10.1 & 11.4 & & 29.30 & {$[25.64 ; 32.96]$} & $14.2 \%$ \\
\hline Somma et $\mathrm{al}^{18}$ & 186 & 42.6 & 7.9 & 98 & 30.2 & 6.8 & & 12.40 & {$[10.64 ; 14.16]$} & $61.3 \%$ \\
\hline Mehrparvar et al ${ }^{5}$ & 142 & 10.3 & 10.6 & 121 & 31.3 & 14.1 & & -21.00 & {$[-24.06 ;-17.94]$} & $20.3 \%$ \\
\hline Korres et $\mathrm{al}^{19}$ & 139 & 64.2 & 44.2 & 32 & 35.3 & 36.1 & & 28.90 & {$[14.39 ; 43.41]$} & $0.9 \%$ \\
\hline Porto et $\mathrm{al}^{20}$ & 60 & 28.2 & 23.8 & 60 & 10.4 & 18.6 & & 17.80 & {$[10.16 ; 25.44]$} & $3.3 \%$ \\
\hline Fixed effect model & 647 & & & 431 & & & & 8.33 & {$[6.95 ; 9.71]$} & $100 \%$ \\
\hline Heterogeneity: I-sq & $\mathrm{red}=\mathrm{s}$ & $\% ;$ ta & qua & $=44$ & $p<$ & & $-40-2002040$ & & & \\
\hline
\end{tabular}

Fig. 9 Analysis for the frequency $16 \mathrm{KHz}$.

\section{Final Comments}

The meta-analysis did not definitely answer the question proposed in this study. It indicates that the frequency of $16 \mathrm{kHz}$ (HFA) is more sensitive in the premature identification of hearing loss in people with normal auditory limits (CG) as well as the frequency of $4 \mathrm{kHz}(\mathrm{CA})$, this one being less expressive (difference of 3 in the MD). This published literature analysis indicates that factors that limit the use of HFA include the absence of standards for this exam in the Brazilian legislation and the cost of the device, even though it useful for monitoring $250 \mathrm{~Hz}$ and $8 \mathrm{KHz}$ frequencies. It also shows the need for further research on the frequencies of $4 \mathrm{kHz}, 6 \mathrm{kHz}, 8 \mathrm{kHz}, 10 \mathrm{kHz}$, $14 \mathrm{kHz}$, and $16 \mathrm{kHz}$, for which we recommend controlling for the methodological bias (age group, presbycusis influence, comorbidity, hearing, gender, noise exposure level at work, time of exposure to noise, and use and type of PPEs). In other words, it is important to define an outline and methodology applied.

\section{References}

1 Ogido R, Costa EA, Machado HC. Prevalência de sintomas auditivos e vestibulares em trabalhadores expostos a ruído ocupacional. Saúde Pública 2009;43(2):377-380

2 -Sakae TM, Sakae O, Spartalis PB Jr, Moretti GF. Perfil epidemiológico e audiológico dos trabalhadores atendidos pelo Serviço Social da Indústria de Brusque - Santa Catarina. AMRIGS 2009; 53(2):144-149

3 -Santana MCCP, Brandão KKCP, Goulart BNG, Chiari BM. Fonoaudiologia e Saúde do Trabalhador: vigilância é Informação para Ação!. CEFAC 2009;11(3):522-528

4 Leão NL, Dias FAM. Perfil audiométrico de indivíduos expostos ao ruído atendidos no núcleo de saúde ocupacional de um hospital do município de Montes Claros, Minas. CEFAC 2010;12(2):242-249

5 Mehrparvar AH, Mirmohammadi SJ, Davari MH, et al. Conventional Audiometry, Extended High-Frequency Audiometry, and DPOAE for Early Diagnosis of NIHL. Iran Red Crescent Med J 2014;16(1):e9628

6 Ganime JF, Almeida LS, Robazzi MLCC, Valenzuela SS, Faleiro SA. 0 ruído como um dos riscos ocupacionais: uma revisão da literatura. Enferm. Glol 2010;19:1-15

7 Portaria do SSST N ${ }^{\circ}$ 19, de 9 de abril de 1998 [Internet]: Brasilia: Ministério do trabalho e do Emprego; 1998 Available at: http:// portal.mte.gov.br/portal-mte/ Accessed Apr 09, 2015
8 Gonçalves CGO, Couto CM, Carraro JM, Leoneli BS. Avaliação da colocação de protetores auriculares em grupos com e sem treinamento. CEFAC 2009;11(2):345-352

9 Ottoni AO, Barbosa-Branco A, Boger ME, Garavelli SL. Study of the noise spectrum on high frequency thresholds in workers exposed to noise. Braz J Otorhinolaryngol 2012; 78(4):108-114

10 Mehrparvar AH, Mirmohammadi SJ, Ghoreyshi A, Mollasadeghi A, Loukzadeh Z. High-frequency audiometry: a means for early diagnosis of noise-induced hearing loss. Noise Health 2011; 13(55):402-406

11 Jacob LCB, Stumpf CC, Bitencourt RF, Marques JM, Puppi C, Gonçalves PT. Avaliação audiológica em indivíduos com neoplasias expostos a agentes quimioterápicos. Fono Atual 2005;8(31): $12-25$

12 Sahyeb DR, Costa Filho OA, Alvarenga KF. Audiometria de alta frequência: estudo com indivíduos audiologicamente normais. Rev Bras Otorrinolaringol (Engl Ed) 2003;69(1):93-99

13 The Cochrane Collaboration [Internet]. Cochrane handbook for systematic reviews of interventions. 2001. [cited Aug 26, 2014]. Available at: http://www.cochrane.org/training/cochrane-handbook. Accessed Apr 09, 2014

14 Biblioteca Virtual em Saúde (BIREME). DEC's - Descritores em Ciências da Saúde. [Internet]. Available at: http://decs.bvs.br/P/ DeCS2013_Alfab.htm. Accessed Jan 16, 2014

15 MacPherson DW. Evidence-based medicine. CMAJ 1995;152(2): 201-204

16 Atallah AN, Trevisani V, Valente O. Tomada de decisões Terapêuticas com Base em Evidências Científicas. AtualizaçãoTerapeutica Manual prático de diagnóstico e tratamento. Available at: http:// www.centrocochranedobrasil.org.br/cms/apl/artigos/artigo_540. pdf. Accessed Feb 9, 2015

17 Pereira MG, Galvão TF. Revisão sistemática Extração, avaliação da qualidade e síntese dos dados para revisão sistemática. Epidemiol Serv Saúde Brasília 2014;23(3):577-578

18 Somma G, Pietroiusti A, Magrini A, et al. Extended high-frequency audiometry and noise induced hearing loss in cement workers. Am J Ind Med 2008;51(6):452-462

19 Korres GS, Balatsouras DG, Tzagaroulakis A, Kandiloros D, Ferekidis E. Extended high-frequency audiometry in subjects exposed to occupational noise. B-ENT 2008;4(3):147-155

20 Porto MA, Gahyva DL, Lauris JR, Lopes AC. Audiometric evaluation in extended high frequencies of individuals exposed to occupational noise. Pro Fono 2004;16(3):237-250

21 Castro IFC, Conde CA, Paiva APQF, Oliveira LTN, Bernardi APA. Estudo do perfil audiométrico em alta freqüência em trabalhadores expostos a ruído. CEFAC 2004;2(6):203-208 